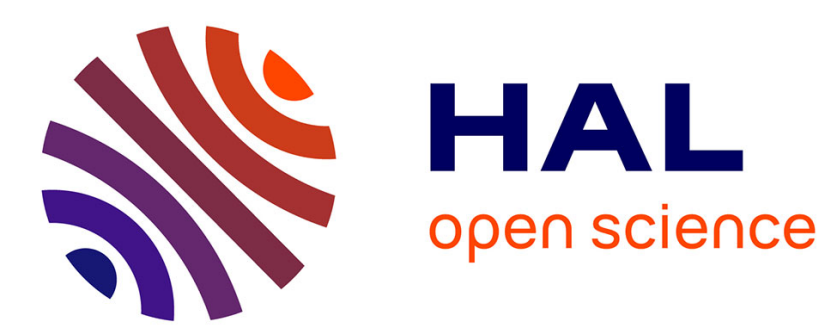

\title{
Biodiesel permeability in polyethylene
}

Emmanuel Richaud, Bruno Flaconnèche, Jacques Verdu

\section{To cite this version:}

Emmanuel Richaud, Bruno Flaconnèche, Jacques Verdu. Biodiesel permeability in polyethylene. Polymer Testing, 2012, 31, pp.170-1076. 10.1016/j.polymertesting.2012.08.003 . hal-01203199

\section{HAL Id: hal-01203199 \\ https://hal.science/hal-01203199}

Submitted on 22 Sep 2015

HAL is a multi-disciplinary open access archive for the deposit and dissemination of scientific research documents, whether they are published or not. The documents may come from teaching and research institutions in France or abroad, or from public or private research centers.
L'archive ouverte pluridisciplinaire HAL, est destinée au dépôt et à la diffusion de documents scientifiques de niveau recherche, publiés ou non, émanant des établissements d'enseignement et de recherche français ou étrangers, des laboratoires publics ou privés. 


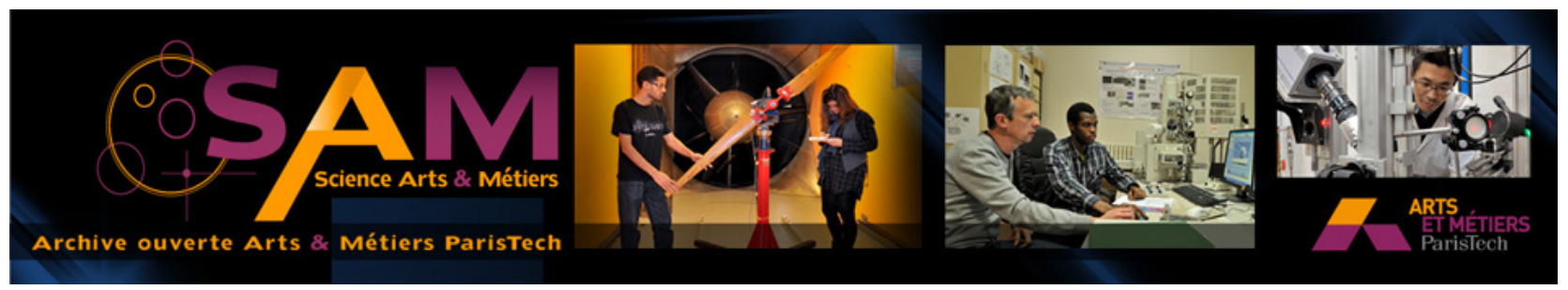

Science Arts \& Métiers (SAM)

is an open access repository that collects the work of Arts et Métiers ParisTech researchers and makes it freely available over the web where possible.

This is an author-deposited version published in: http://sam.ensam.eu

Handle ID: .http://hdl.handle.net/10985/10103

\section{To cite this version :}

Emmanuel RICHAUD, Bruno FLACONNÈCHE, Jacques VERDU - Biodiesel permeability in polyethylene - Polymer Testing - Vol. 31, p.170-1076 - 2012 


\title{
Biodiesel permeability in polyethylene
}

\author{
Emmanuel Richaud ${ }^{\mathrm{a}, *}$, Bruno Flaconnèche ${ }^{\mathrm{b}}$, Jacques Verdu ${ }^{\mathrm{a}}$ \\ a Arts et Metiers ParisTech, CNRS, PIMM UMR 8006, 151 boulevard de l'Hôpital, 75013 Paris, France \\ ${ }^{\mathrm{b}}$ IFP Energies Nouvelles, 1 et 4 avenue du Bois-Préau, 92852 Rueil-Malmaison Cedex, France
}

\author{
Keywords: \\ Polyethylene \\ Biodiesels \\ Diffusivity \\ Solubility \\ Permeability \\ Modelling
}

\begin{abstract}
A B S T R A C T
This paper reports solubility and diffusivity data for soy and rapeseed methyl esters in polyethylene together with comparisons with methyl oleate and linoleate. These data showed that there is no significant difference in diffusivity and solubility between all these penetrants. Data were used to discuss the reliability of predictive models for diffusion and solubility of additive type molecules into semi-crystalline thermoplastic polymers. Permeability data were monitored by a new device, the results from which are in reasonable agreement with theoretical considerations on solubility and diffusivity. They also showed that biodiesels are less aggressive towards polyethylene than diesel from a petrochemical source.
\end{abstract}

\section{Introduction}

A recent trend in the automotive industry is to replace fossil fuels by fuels from vegetal sources. Methyl esters from vegetal sources are made of several kinds of saturated and unsaturated linear hydrocarbon chains [1]. There is a considerable literature dealing with their production, but there are only few data showing their good compatibility with the various polymers employed in the fuel system [2], which is necessary for their sustained use. In particular, little is known on interactions of fatty esters with polyethylene ( $\mathrm{PE}$ in the following). Non-empirical lifetime assessment is possible if:

- The permeation kinetics of methyl esters in polymer can be predicted for a given temperature, sample thickness, sample crystalline ratio and biodiesel type,

- Structure-properties relationships are available to determine the effect of oil absorption on mechanical properties: Young's modulus, yield stress, crazing critical strain, etc...

\footnotetext{
* Corresponding author.

E-mail address: emmanuel.richaud@ensam.eu (E. Richaud).
}

The aim of this article is to study the transport properties in PE of soy and rapeseed oils and answer the following questions:

- Are the biodiesels from vegetable source more aggressive towards PE than classical diesels derived from crude oil? Note that the answer to this question comes also from the relative oxidizability of matrix and penetrant: if the penetrant is much more oxidizable than polymer, one can imagine that absorbed penetrant may promote oxidative degradation of the matrix by a co-oxidation mechanism. This question is under investigation in our laboratory

- Despite the relative complexity of vegetable methyl ester composition, do model systems exist?

- Can permeation properties be modelled in order to build a predictive tool? Can the model take into account the morphological differences between all commercial grades of PE?

Methyl oleate (C18-1) and methyl linoleate (C18-2) being the major components of the vegetable oils [2], it seemed to us interesting to study their permeability independently and to compare their transport properties to those of vegetable methyl esters. This paper is also aimed at 


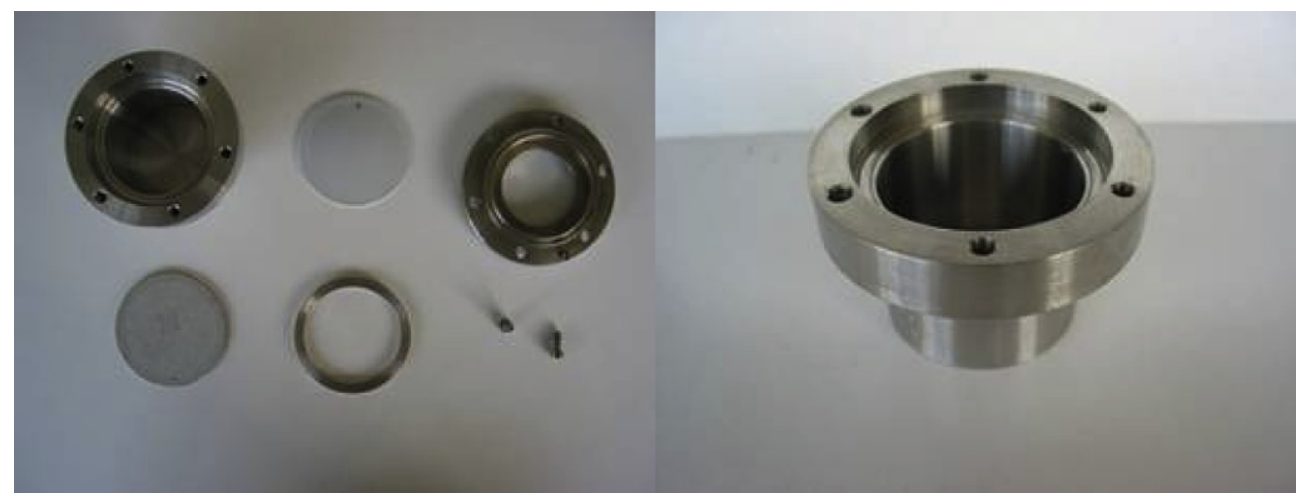

Fig. 1. Pictures of a liquid permeation cell.

validating a new cell designed for measuring fluid permeability through polymers.

\section{Experimental}

\subsection{Materials}

\subsubsection{Polyethylene}

The polyethylene was a pipe grade supplied by Borealis as additive-free powder. This was blended with $0.3 \%(\mathrm{w} / \mathrm{w})$ Irganox 1010 and then extruded using a Brabender twinscrew extruder to obtain $150 \mu \mathrm{m}$ films using the following conditions (Tzone $1=150^{\circ} \mathrm{C}$, Tzone $2=180^{\circ} \mathrm{C}$, Tzone $3=200{ }^{\circ} \mathrm{C}$ ), torque $=400 \mathrm{~N} \mathrm{~m}$, rev $=10 \mathrm{tr} \mathrm{min}^{-1}$.

Several PE extruded foils were then pressed together at $130{ }^{\circ} \mathrm{C}$ using a laboratory press (Brigite Instruments) in order to obtain $600 \pm 100 \mu \mathrm{m}$ films, this thickness being optimum for the diffusion experiments under study. The polymer density was about 0.935 . Melting point was found to be close to $128{ }^{\circ} \mathrm{C}$. Crystalline ratio was estimated to be close to $40 \%$ from measurement of melting enthalpy by differential scanning calorimetry using $\Delta \mathrm{H}_{100}=290 \mathrm{~J} \mathrm{~g}^{-1}$ for a $100 \%$ crystalline material.

Some comparisons were done with a commercial grade of HDPE (polyethylene 2 in the following) supplied as $0.2 \%$ carbon black filled tanks made by extrusion blowing. $\mathrm{M}_{\mathrm{W}}$ was estimated to be close to $225 \mathrm{~kg} \mathrm{~mol}^{-1}$ by dynamic rheometry. Crystalline ratio was estimated to be close to $60 \%$ from measurement of melting enthalpy.

\subsubsection{Penetrants}

Commercial methyl oleate (CAS 112-62-9, ref 268038 supplied by Sigma Aldrich) and methyl linoleate (CAS 11263-0, ref 62290 supplied by Sigma Aldrich) were used for sorption experiments. Rapeseed and soy methyl esters were kindly supplied by Sofiproteol.
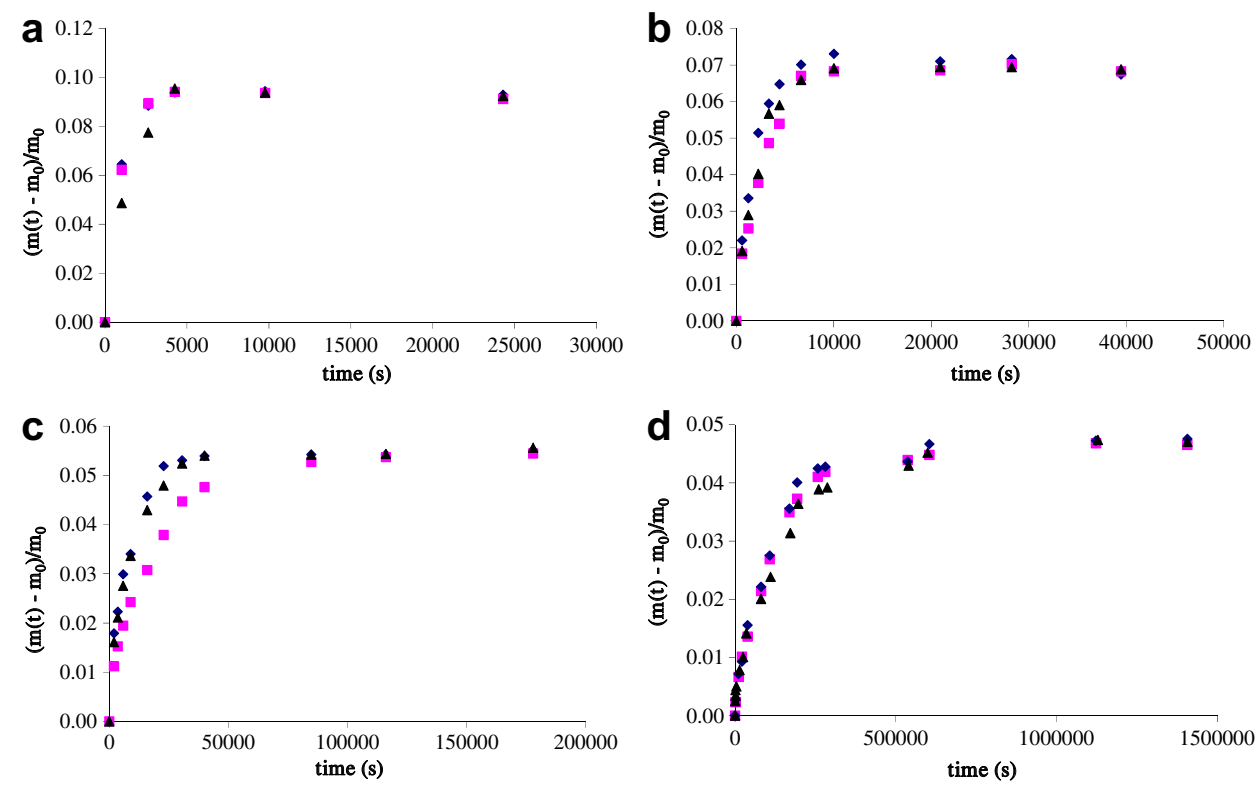

Fig. 2. Kinetic curves for mass uptake of rapeseed methyl ester sorption into polyethylene 1 at $75{ }^{\circ} \mathrm{C}(\mathrm{a}), 60{ }^{\circ} \mathrm{C}(\mathrm{b}), 45^{\circ} \mathrm{C}(\mathrm{c})$ and room temperature (d). 
Table 1

Average equilibrium mass fractions and fatty esters concentrations at the four temperatures under study.

\begin{tabular}{|c|c|c|c|c|c|c|c|c|}
\hline \multirow[t]{2}{*}{$\mathrm{T}\left({ }^{\circ} \mathrm{C}\right)$} & \multicolumn{2}{|c|}{ Methyl oleate } & \multicolumn{2}{|c|}{$\begin{array}{l}\text { Methyl } \\
\text { linoleate }\end{array}$} & \multicolumn{2}{|c|}{$\begin{array}{l}\text { Rapeseed } \\
\text { methyl ester }\end{array}$} & \multicolumn{2}{|c|}{$\begin{array}{l}\text { Soy methyl } \\
\text { ester }\end{array}$} \\
\hline & $\mathrm{W}_{\mathrm{eq}}$ & $\begin{array}{l}\mathrm{C} \\
\left(\mathrm{mol} \mathrm{l}^{-1}\right)\end{array}$ & $\mathrm{w}_{\mathrm{eq}}$ & $\begin{array}{l}\mathrm{C} \\
\left(\mathrm{mol} \mathrm{l}^{-1}\right)\end{array}$ & $\mathrm{w}_{\mathrm{eq}}$ & $\begin{array}{l}\mathrm{C} \\
\left(\mathrm{mol} \mathrm{l}^{-1}\right)\end{array}$ & $\mathrm{w}_{\mathrm{eq}}$ & $\begin{array}{l}\mathrm{C} \\
\left(\mathrm{mol} \mathrm{l}^{-1}\right)\end{array}$ \\
\hline 75 & 0.116 & 0.666 & 0.092 & 0.542 & 0.095 & 0.555 & 0.092 & 0.539 \\
\hline 60 & 0.070 & 0.423 & 0.064 & 0.386 & 0.071 & 0.425 & 0.069 & 0.414 \\
\hline 45 & 0.056 & 0.343 & 0.051 & 0.312 & 0.055 & 0.335 & 0.054 & 0.328 \\
\hline 23 & 0.047 & 0.288 & 0.042 & 0.257 & 0.047 & 0.290 & 0.047 & 0.291 \\
\hline
\end{tabular}

\subsection{Characterization}

\subsubsection{Solubility and diffusivity measurements}

$5 \mathrm{~cm} \times 2 \mathrm{~cm}$ samples were immersed in methyl esters at various temperatures from room temperature to $75{ }^{\circ} \mathrm{C}$ in ventilated ovens. Methyl esters were thermally equilibrated overnight prior to exposure. It was ensured that PE samples were totally immersed under a huge quantity of methyl ester, and that PE samples were not mechanically stressed by vessel walls. Each measurement was made in triplicate.

After exposure, immersed samples were quickly removed from the methyl ester bath and then dried with a clean absorbing paper, weighed and immediately reimmersed into methyl ester. Time for this procedure was systematically less than $3^{\circ} \mathrm{min}$. It was again checked that samples were not mechanically stressed by the vessel. It was assumed that oxidation induced changes in methyl esters composition were negligible within the duration of the experiments.
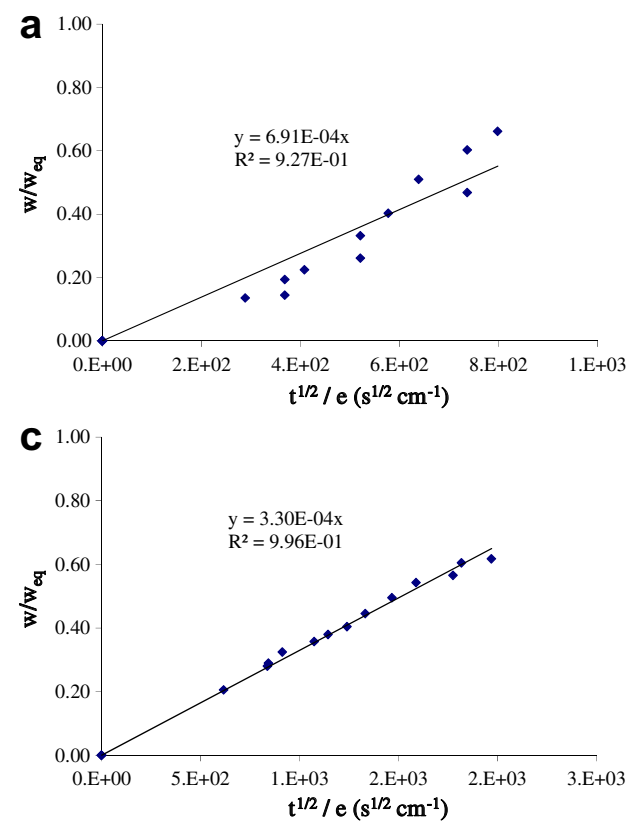

\subsubsection{Permeability measurement}

One of the methods classically used for the determination of the coefficient of fluid permeability through polymeric materials (elastomers, thermoplastics...) is the "Weight Loss" method. The method allows the amount of diffusing molecules crossing the material to be determined by the weight loss of a metallic cell containing the fuel of interest and closed by the polymer membrane to be studied (Fig. 1). To carry out the study, this cell is periodically weighed (period of once per day to several times per month according to recorded losses) on a precision balance to follow the global weight loss of the assembly. The Fig. 1 represents experimental curves of weight loss with time. Permeability (denoted by Pe in the following) is estimated from the slope by the formula:

$P e=\frac{\mathrm{m} \cdot \mathrm{e}}{\mathrm{S} \cdot \mathrm{t}}$

where:

- Pe is expressed in $\mathrm{g} \mathrm{cm} \mathrm{cm}^{-2} \mathrm{~s}^{-1}$,

- $\mathrm{m}$ is the lost mass (in $\mathrm{g}$ ) during the time duration $\mathrm{t}$ (in $\mathrm{s}$ ),

- e is the polymer thickness (in $\mathrm{cm}$ ),

- $\mathrm{s}$ is the sample surface in contact with methyl ester (in $\mathrm{cm}^{2}$ ).

\section{Results}

\subsection{Solubility measurements}

The kinetic curves of mass uptake are presented in Fig. 2 for PE + rapeseed methyl ester. They display the classical shape with maximal uptake rate at the beginning of exposure which then decreases continuously. A pseudo
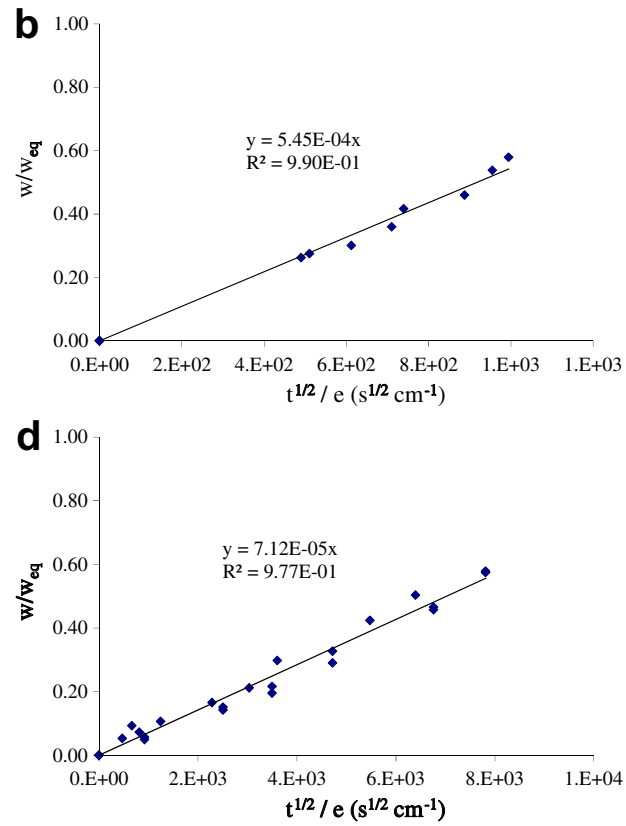

Fig. 3. $\mathrm{w} / \mathrm{w}_{\mathrm{eq}}$ against $\left(\mathrm{t}^{1 / 2}\right) / \mathrm{e}$ for rapeseed methyl ester sorption into polyethylene 1 at $75^{\circ} \mathrm{C}(\mathrm{a}), 60{ }^{\circ} \mathrm{C}(\mathrm{b}), 45^{\circ} \mathrm{C}(\mathrm{c})$ and room temperature $(\mathrm{d})$. 


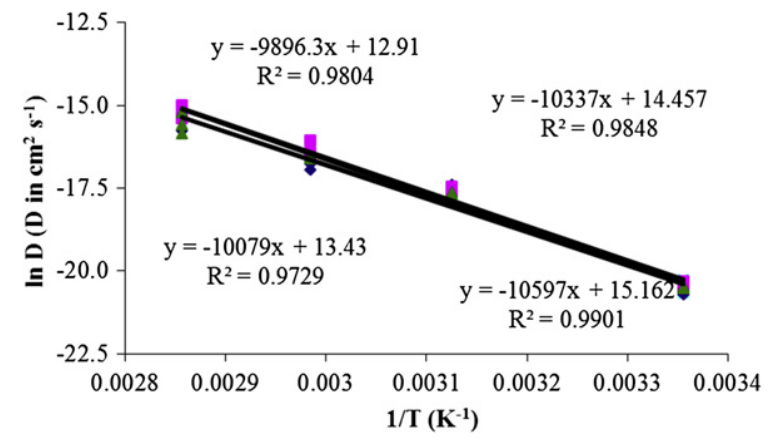

Fig. 4. Arrhenius plot of diffusivity in polyethylene 1 for rapeseed $(X)$, soy $(\pi)$, oleate $(\square)$ and linoleate $(\diamond)$ methyl esters.

plateau is reached at long exposure times. The relative mass uptake (denoted by w) is defined by:

$\mathrm{w}=\frac{\mathrm{m}-\mathrm{m}_{0}}{\mathrm{~m}_{0}}$

where $\mathrm{m}_{0}$ and $\mathrm{m}$ are, respectively, the sample masses before and after exposure. The corresponding mass fractions $\mathrm{w}_{\mathrm{eq}}$ values are given in Table 1 . It is well known that penetrants such as fatty esters under study are only soluble in the amorphous phase of PE. Their local equilibrium concentration is given by:

$c=\frac{w_{e q} \cdot \rho_{a}^{P E}}{M_{e s t e r} \cdot\left(1-x_{C}\right) \cdot\left(1+w_{e q}\right)}$

where:

- $\rho_{\mathrm{a}}^{\mathrm{PE}}$ is the density of the PE amorphous phase containing the penetrants (expressed in $\mathrm{g} \mathrm{l}^{-1}$ ).

- Mester is the penetrant molar mass (in $\mathrm{g} \mathrm{mol}^{-1}$ ).

- $\mathrm{x}_{C}$ is the crystalline ratio.

For the sake of simplicity, it will be assumed that:

- the mixture density is the same for penetrant and PE amorphous phase,

- the molar mass of soy and rapeseed methyl ester are equal to the weight average molar mass of each penetrant.

The values of $c$ are given in Table 1 and show no major differences in solubility between the investigated methyl esters, no doubt because they have very close polarity.

\subsection{Diffusivity measurements}

Several methods are reported to measure the diffusivity of a chemical in a polymer [3]. To analyze diffusion kinetics, it seemed to us interesting to replot $w / w_{\text {eq }}$ against $\left(t^{1 / 2}\right) / e, e$ being the sample thickness. It can be recalled that, according to Fick's law, w/weq must be proportional to $\left(\mathrm{t}^{1 / 2}\right) / \mathrm{e}$ at short times such as typically $\mathrm{w} / \mathrm{w}_{\mathrm{eq}}<0.6$ :

$\frac{w}{w_{e q}}=\frac{4}{e} \cdot \sqrt{\frac{D \cdot t}{\pi}}$

The plots are represented in Fig. 3 for PE + rapeseed methyl ester. Diffusion appears Fickian except at the highest temperature $\left(75^{\circ} \mathrm{C}\right)$ for all the samples, for which the curves display a sigmoidal shape with the Arrhenius diagram in Fig. 4. Their quantitative exploitation is given in Table 2. It is obvious that penetrants have very close diffusivity, possibly because they are all linear molecules with relatively close molar mass (ca $290 \mathrm{~g} \mathrm{~mol}^{-1}$ ).

\subsection{Permeation tests}

A typical curve of methyl ester flow through a PE sheet is shown in Fig. 5. The weight change appears almost proportional to elapsed time, indicating that the permeation process reaches rapidly a steady state. The permeability coefficient (denoted by Pe, expressed in $\mathrm{g} \mathrm{cm} \mathrm{cm} \mathrm{cm}^{-2} \mathrm{~s}^{-1}$ ) can be determined from the slope of the straight line. Measured permeabilities are gathered in Table 3 together with an estimation of its activation energy, assuming as a first approach that permeability obeys Arrhenius law [4].

Since solubilities of the three methyl esters under consideration are almost equal (Table 2), differences in permeability values must result from differences in diffusivities, which will be discussed later.

The permeability of diesels and biodiesels from vegetal or mineral source is compared in Fig. 6. They confirm that permeation properties of methyl esters in polyethylene are very close, consistent with results reported above. It seems also that biodiesels are less permeable than diesels derived from oil and their mixtures with biodiesels.

\section{Discussion}

\subsection{Prediction of the solubility}

To interpret the thermal dependance of solubility, we tried to determine the Henry's solubility coefficient $S$ defined by [5]:

Table 2

Diffusion coefficients (in $\mathrm{cm}^{2} \mathrm{~s}^{-1}$ ) estimated from the slopes of Fig. 4 together with corresponding Arrhenius parameters.

\begin{tabular}{cccccc}
\hline & $75{ }^{\circ} \mathrm{C}$ & $60{ }^{\circ} \mathrm{C}$ & $45{ }^{\circ} \mathrm{C}$ & $25{ }^{\circ} \mathrm{C}$ & $\operatorname{ln~}_{0}\left(\mathrm{D}_{0}\right.$ in $\left.\mathrm{cm}^{2} \mathrm{~s}^{-1}\right)$ \\
\hline Methyl oleate & $2.40 \times 10^{-7}$ & $8.21 \times 10^{-8}$ & $2.36 \times 10^{-8}$ & $1.39 \times 10^{-9}$ & 14.46 \\
Methyl linoleate & $1.96 \times 10^{-7}$ & $5.02 \times 10^{-8}$ & $2.30 \times 10^{-8}$ & $1.13 \times 10^{-9}$ & 13.43 \\
Rapeseed methyl ester & $1.82 \times 10^{-7}$ & $6.22 \times 10^{-8}$ & $2.12 \times 10^{-8}$ & $1.26 \times 10^{-9}$ & 12.91 \\
Soy methyl ester & $2.56 \times 10^{-7}$ & $6.48 \times 10^{-8}$ & $2.10 \times 10^{-8}$ & $1.25 \times 10^{-9}$ & 15.16 \\
\hline
\end{tabular}




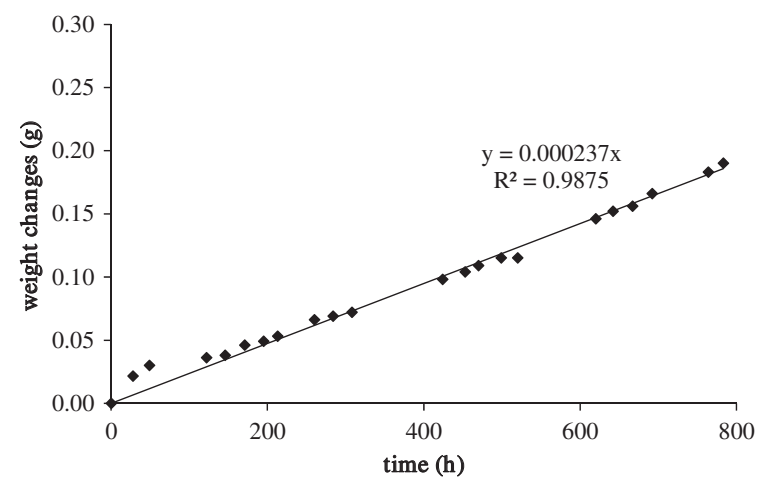

Fig. 5. Typical curve for permeability measurement (here for a $30 \%$ soy methyl ester - 70\% rapeseed methyl ester) in polyethylene 2 at $80{ }^{\circ} \mathrm{C}$.

$C=S \times P$

where $\mathrm{P}$ (here equal to the saturated vapor pressure $\mathrm{P}_{\text {sat }}$ of the methyl ester under study, calculated from methyl ester boiling point $\mathrm{T}_{\mathrm{b}}$ using Antoine's law:

$\log P_{\text {sat }}=A-\frac{B}{T+C}$

$\mathrm{P}_{\text {sat }}$ being expressed here in $\mathrm{Pa}$ and $\mathrm{T}$ in $\mathrm{K}, \mathrm{A} \mathrm{B}$ and $\mathrm{C}$ coefficient (Table 4) from [6,7]. The values of $S$ determined for methyl oleate and methyl linoleate are listed in Table 4. An Arrhenius plot of $\mathrm{S}$ is shown in Fig. 7 and may be used as model for solubility of other methyl esters of vegetable oil.

A positive curvature is observed, revealing that the solubility process cannot be represented by a single Arrhenius term. The simplest model could be the sum of two Arrhenian terms:

$S=S_{01} \cdot \exp \left(-\frac{\Delta H_{S 1}}{R T}\right)+S_{02} \cdot \exp \left(-\frac{\Delta H_{S 2}}{R T}\right)$

This behavior has been previously observed, for instance by McCall et al [8] for water solubility in PE. The authors interpreted this result as follows:

- the term of lowest activation energy corresponds to the dissolution in the apolar regions of PE.

- the term of the highest activation energy corresponds to the interaction of methyl esters with polar sites (structural irregularities) of PE or the adsorption of methyl esters at the surface of crystalline lamellae.

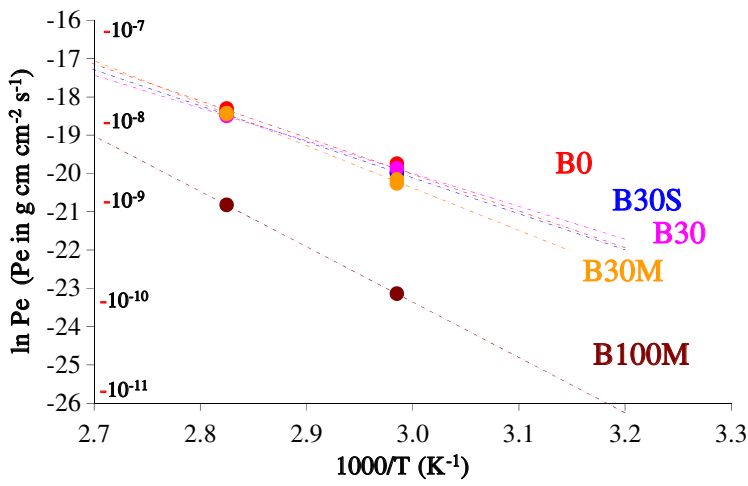

Fig. 6. Comparison of permeability of diesel (B0), mixture of soy and rapeseed methyl ester B100) and mixture of 70\% diesel with 30\% soy methyl ester (B30S), or 30\% rapeseed methyl ester (B30R) or $30 \%$ of soy $(9 \%)+$ rapeseed $(21 \%)$ methyl ester mixture (B30M).

It remains, however, to calculate the corresponding 4 parameters, without to our knowledge the existence of reliable structure - solubility relationships in the case of semi-crystalline polymer and liquid penetrants close to the case under study.

\subsection{Prediction of diffusivity}

The diffusion of a chemical into a polymer is facilitated by decreasing the penetrant size (expressed by its specific molar volume $\mathrm{V}^{*}$ ) and also increases with increasing free volume $V_{f}$, as expressed by the Cohen and Turnbull theory [9]:

$D=A \cdot \exp \left(-\gamma \frac{V^{*}}{V_{f}}\right)$

in which $\gamma$ is a factor ranging between 0.5 and 1 .

This theory has led to very sophisticated theories permitting prediction for cases in which penetrant bring its own free volume, thus facilitating the diffusion, but requiring a huge number of parameters to be determined [10], which seems out of reach for complex mixtures such as biodiesels.

Several models aimed at correlating molar mass of diffusant, temperature and polymer nature have been proposed by Helmroth [11,12], Limm and Hollifield [13], Mercea [14], Piringer [15], and Begley [16]. It is noteworthy that the correlation between $\ln \mathrm{D}$ and $\mathrm{M}$ works particularly well for penetrants having a linear structure [17], which is the case here (some differences appear for polycyclic and branched penetrants molecules, with distortions in the

Table 3

Permeability measurement, corresponding activation energies for polyethylene 2 together with estimation of thermodependance of diffusion.

\begin{tabular}{llllll}
\hline & $\mathrm{Pe}\left(60^{\circ} \mathrm{C}\right)$ & $\mathrm{Pe}\left(80^{\circ} \mathrm{C}\right)$ & $\Delta \mathrm{H}_{\mathrm{Pe}}\left(\mathrm{kJ} \mathrm{mol}^{-1}\right)$ & $\Delta \mathrm{H}_{\mathrm{sol}}\left(\mathrm{kJ} \mathrm{mol}^{-1}\right)$ & $\Delta \mathrm{H}_{\mathrm{D}}(\mathrm{kJ} \mathrm{mol}$ \\
\hline Methyl oleate & $1.14 \times 10^{-10}$ & $1.32 \times 10^{-9}$ & 119.4 & 24 & 95.7 \\
Soy methyl ester & $1.56 \times 10^{-10}$ & $1.53 \times 10^{-9}$ & 111.6 & 18.1 & 93.5 \\
Rapeseed methyl ester & $1.44 \times 10^{-10}$ & $9.96 \times 10^{-10}$ & 94.5 & 17.8 & 76.7 \\
30\% soy + 70\% rapeseed & $9.0 \times 10^{-11}$ & $9.0 \times 10^{-10}$ & 112.5 & - & - \\
\hline
\end{tabular}


Table 4

Antoine's law coefficient for methyl oleate and methyl linoleate.

\begin{tabular}{llllr}
\hline & $\mathrm{T}_{\mathrm{b}}(\mathrm{K})$ & $\mathrm{A}$ & $\mathrm{B}$ & \multicolumn{1}{c}{$\mathrm{C}$} \\
\hline C18:1 & 622 & 9.9155 & 2583.52 & -96.15 \\
C18:2 & 639 & 8.2175 & 1450.62 & -188.03 \\
\hline
\end{tabular}

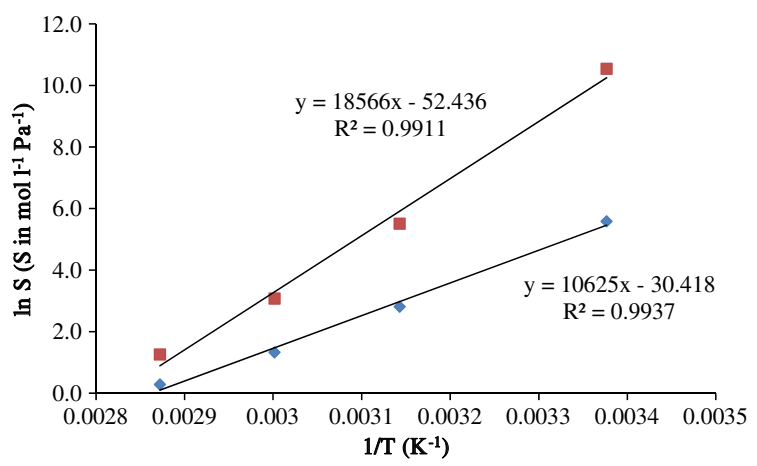

Fig. 7. Arrhenius diagram of $S=c / P_{\text {sat }}$ for methyl oleate ( $\square$ ) and methyl linoleate (

Table 5

Parameters for molecular models for LDPE.

\begin{tabular}{lllllllll}
\hline & $\mathrm{a}_{0}$ & $\mathrm{a}_{1}$ & $\mathrm{a}_{2}$ & $\mathrm{~b}_{2}$ & $\mathrm{a}_{3}$ & $\mathrm{a}_{4}$ & $\mathrm{~b}_{4}$ & $\mathrm{a}_{5}$ \\
\hline Begley & $10^{4}$ & 11.5 & -0.1351 & $2 / 3$ & 0.003 & -10454 & 0 & 0 \\
Piringer & $10^{4}$ & 11 & 0 & 0 & -0.0101 & -10450 & 0 & 0 \\
Mercea & $10^{4}$ & 10.6 & -0.13 & $2 / 3$ & 0 & -10450 & 0 & 0 \\
Limm & $\exp (-4.16)$ & 0 & 0.555 & $1 / 2$ & 0 & -1140.5 & $1 / 3$ & 0 \\
\hline
\end{tabular}

Arrhenius diagram describing the thermal dependence of diffusivity [18]). The general form of these models is:

$D=a_{0} \cdot \exp \left(a_{1}+a_{2} \cdot M^{b_{2}}+a_{3} \cdot M+\frac{a_{4} \cdot M^{b_{4}}+a_{5}}{T}\right)$

$\mathrm{D}$ is expressed in $\mathrm{cm}^{2} \mathrm{~s}^{-1}, \mathrm{M}$ in $\mathrm{g} \mathrm{mol}{ }^{-1}$ and $\mathrm{T}$ in $\mathrm{K}$. Coefficients for LDPE and HDPE are given in Tables 5 and 6.

It seems that diffusion coefficient values and corresponding activation energy for diffusion in polyethylene 1 (Table 2) are conveniently simulated by some of these models, for example Begley's model for LDPE, which is not surprising for the PE used in this study and also in other semicrystalline polymers [19]]. It is in particular noteworthy that those models predict an activation energy ca $85 \mathrm{~kJ} \mathrm{~mol}^{-1}$ (Fig. 4), in excellent agreement with our experimental results (Table 2 ).

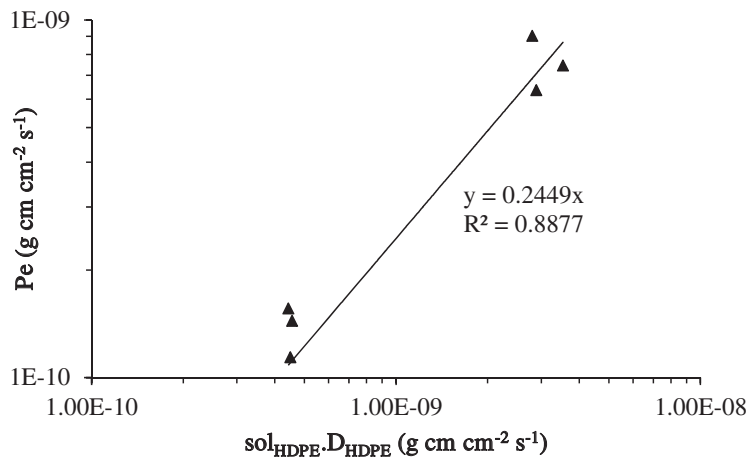

Fig. 8. Comparison of experimental and 'predicted' (see text) permeability values.

\subsection{Prediction of the permeability}

Measured values for permeability of methyl oleate, soy methyl ester, rapeseed methyl ester and a mix of rapeseed and soy methyl esters are gathered in Table 3.Since:

$\mathrm{Pe} \sim \mathrm{sol} \times \mathrm{D}$

$\Delta H_{D}=\Delta H_{P e}-\Delta H_{s o l}$

The solubility actually displays curvature in the Arrhenius diagram. However, we will approximate here it to an Arrhenius function in the "high" temperature range (45$75{ }^{\circ} \mathrm{C}$ ) for roughly estimating $\Delta \mathrm{H}_{\text {sol }}$.

This result suggests that $\Delta \mathrm{H}_{\mathrm{D}}$ is certainly close to $95 \mathrm{~kJ} \mathrm{~mol}^{-1}$ (Table 4). It corresponds well to the activation energy predicted by molecular models for a HDPE such as polyethylene 2 (see Tables 5 and 6 ).

It seemed to us interesting to compare the measured values of permeability with a prediction from solubility and diffusivity measured values. To that purpose:

- D was calculated from the model by Begley's equation using HDPE coefficient (and denoted by $\mathrm{D}_{\mathrm{HDPE}}$ )

- $s$ was estimated from measured solubility values (see Table 2) corrected for crystallinity by the formula: $\mathrm{s}_{\mathrm{HDPE}}=\mathrm{s}_{\mathrm{LDPE}} \cdot\left(1-\mathrm{x}_{\mathrm{CHDPE}}\right) /\left(1-\mathrm{x}_{\mathrm{CLDPE}}\right)$ using crystallinity ratio values determined from DSC measurements (see 'Experimental' section).

The comparison is presented in Fig. 8. A factor ca 4 is observed between 'predicted' and measured permeability values. Even if the agreement between both values can be improved, it seems that the new cell developed for this work is a promising tool for studying permeability of chemicals through polymers.

Table 6

Parameters for molecular models for HDPE.

\begin{tabular}{|c|c|c|c|c|c|c|c|c|}
\hline & $a_{0}$ & $a_{1}$ & $a_{2}$ & $\mathrm{~b}_{2}$ & $a_{3}$ & $\mathrm{a}_{4}$ & $\mathrm{~b}_{4}$ & $a_{5}$ \\
\hline Begley & $10^{4}$ & 11.5 & -0.1351 & $2 / 3$ & 0.003 & -10454 & 0 & -1577 \\
\hline Piringer & $10^{4}$ & 8 & 0 & 0 & -0.0101 & -10450 & 0 & 0 \\
\hline Mercea & $10^{4}$ & 8.8 & -0.13 & $2 / 3$ & 0 & -10450 & 0 & 0 \\
\hline Limm & $\exp (-0.9)$ & 0 & 0.819 & $1 / 2$ & 0 & -1760.7 & $1 / 3$ & 0 \\
\hline
\end{tabular}




\section{Conclusions}

This paper reports solubility, diffusion and permeability data for two biodiesel compounds (soy and rapeseed methyl esters) and two model systems (methyl oleate and methyl linoleate) in two polyethylenes in the $25-75^{\circ} \mathrm{C}$ temperature range. Solubility ranges from c.a. $5 \%$ at the lowest temperature to more than $10 \%$ at the highest, and diffusion increases from c.a. $10^{-9} \mathrm{~cm}^{2} \mathrm{~s}^{-1}$ at $25{ }^{\circ} \mathrm{C}$ to more than $10^{-7} \mathrm{~cm}^{2} \mathrm{~s}^{-1}$ at $75^{\circ} \mathrm{C}$. The corresponding activation energies are close to 85 and $90 \mathrm{~kJ} \mathrm{~mol}^{-1}$ for diffusion in LDPE and HDPE, respectively, and about $110 \mathrm{~kJ} \mathrm{~mol}^{-1}$ for permeability in HDPE. These data were used for comparisons with existing predictive models for solubility and diffusivity. In particular, curvature observed in the Arrhenius diagram of solubility was satisfyingly modeled by modifying the Henry's law by supposing a dual dissolution process in polyethylene. It was also checked that some molecular models based on correlation between diffusion coefficient, temperature and penetrant molar mass can simulate the measured diffusion coefficients. A new device was employed for measuring fuel permeability through polymers. Its measurements were tentatively validated from comparisons with the above reported values. It showed that biodiesels are less aggressive towards PE than mineral ones.

\section{Acknowledgments}

ANR BioCarbMat (pole de compétitivité Mov'eo) granted by French government.

\section{References}

[1] A.S.M.A. Haseeb, T.S. Jun, M.A. Fazal, H.H. Masjuk, Degradation of physical properties of different elastomers upon exposure to palm biodiesel, Energy 36 (3) (2011) 1814.

[2] A. Demirbas, Comparison of transesterification methods for production of biodiesel from vegetable oils and fats, Energy Convers. Manage. 49 (1) (2008) 125
[3] I.D. Rosca, J.M. Vergnaud, J. Ben Abdelouahab, Determination of the diffusivity of a chemical through a polymer, Polym. Test. 20(1)(2000) 59

[4] K. Galić, N. . Ciković, Permeability characterisation of solvent treated polymer materials, Polym. Test. 20 (6) (2001) 599.

[5] D.W. Van Krevelen, K. Te Nijenhuis, Properties of Polymers, Their Correlation with Chemical Structure; Their Numerical Estimation and Prediction from Additive Group Contributions, fourth ed. Elsevier, Amsterdam, 2009, Chap 18 pp. 655-702.

[6] W. Yuan, A.C. Hansen, Q. Zhang, Vapor pressure and normal boiling point predictions for pure methyl esters and biodiesel fuels, Fuel 84 (7-8) (2005) 943.

[7] D. Lipkind, Y. Kapustin, P. Umnahanant, J.S. Chikos, The vaporization enthalpies and vapor pressures of a series of unsaturated fatty acid methyl esters by correlation gas chromatography, Thermochim Acta 456 (2) (2007) 94.

[8] D.W. McCall, D.C. Douglass, L.L. Blyler Jr., G.E. Johnson, L.W. Jelinski, H.E. Bair, Solubility and diffusion of water in low-density polyethylene, Macromolecules 17 (9) (1984) 1644.

[9] M.H. Cohen, D. Turnbull, Molecular transport in liquids and glasses, J. Chem. Phys. 31 (5) (1959) 1164.

[10] J.S. Vrentas, J.L. Duda, Diffusion in polymer-solvent systems - 2. A predictive theory for the dependence of diffusion coefficients on temperature, concentration and molecular weight, J. Polym. Sci. Polym. Phys. Ed. 15 (3) (1977) 417.

[11] E. Helmroth, C. Varekamp, M. Dekker, Stochastic modelling of migration from polyolefins, J. Sci. Food Agr 85 (6) (2005) 909.

[12] E. Helmroth, R. Rijk, M. Dekker, W. Jongen, Predictive modelling of migration from packaging materials into food products for regulatory purposes, Trends Food Sci. Tech. 13 (3) (2002) 102.

[13] W. Limm, H.C. Hollifield, Modelling of additive diffusion in polyolefins, Food Addit Contam. 13 (8) (1996) 949.

[14] J. Brandsch, P. Mercea, O. Piringer, Modeling of additive diffusion coefficients in polyolefins. Symposium Series, in: S.J. Risch (Ed.) Food Packaging Testing Methods and Applications, vol. 753, ACS, Washington DC, 2000, pp. 27-36.

[15] O. Piringer, Evaluation of plastics for food packaging, Food Addit Contam. 11 (1994) 221.

[16] T. Begley, L. Castle, A. Feigenbaum, R. Franz, K. Hinrichs, T. Lickly, P. Mercea, M. Milana, A. O’Brien, S. Rebre, R. Rijk, O. Piringer, Food Addit Contam. 22 (1) (2005) 73.

[17] A. Reynier, P. Dole, S. Humbel, A. Feigenbaum, Diffusion coefficients of additives in polymers. I. Correlation with geometric parameters, J Appl. Polym. Sci. 82 (10) (2001) 2422

[18] A. Bellili, N. David, B. Vandame, Q. Wang, Y. Goutille, E. Richaud, Diffusion and solubility of mineral oils through ethylene-viny acetate copolymer, Polym. Test. 31 (2) (2012) 236.

[19] F. Welle, R. Franz, Diffusion coefficients and activation energies of diffusion of low molecular weight migrants in poly(ethylene terephthalate) bottles, Polym. Test. 31 (1) (2012) 93. 